\title{
ВИЗАНТИЙСКОЕ ПРАВОСЛАВИЕ
}

www.volsu.ru

DOI: https://doi.org/10.15688/jvolsu4.2019.6.25

UDC 94“04/14”: 159.961 .44

Submitted: 01.02.2019

LBC 63.3(0)4-7

Accepted: 24.07.2019

\section{HAIR-SNAKES. TO THE ISSUE OF THE SEMANTICS OF BYZANTINE PHYLACTERIES WITH "HYSTERA"}

\author{
Nikolay D. Barabanov \\ Volgograd State University, Volgograd, Russian Federation
}

\begin{abstract}
Introduction. The article is devoted to analyzing the specific type of Byzantine phylacteries (amulets), which are a vivid manifestation of folk beliefs that combine pagan, magical and Christian components. The author talks about the so-called "coils" - pendants with the image of a head with reptiles instead of hair or simply in combination with snakes. Many of them have a magical inscription mentioning "hysteria" (uterus), which can be understood as this particular organ, as well as various harmful entities. For this reason, there is a problem of correlation of the image and the magic inscription. But the article attempts to interpret the serpentine composition in the context of its functional purpose. Methods. In historiography, there are many opinions about what the images could represent on this type of monuments. At different times, researchers saw in the image of a head with snakes Medusa Gorgon, the dragon-Satan, Russian Aphrodite - goddess Lada, Abrasax, Sophia of Ophites, Moses' brazen serpent, Eve and the devil, the seven-headed serpent and seven deadly sins, sisters-Likhoradkas, the dragon from the Apocalypse, the serpent of Aesculapius transformed into Satan. In addition, the composition was recognized as a "portrait" of the demon and his machinations elevated to the image of Khnubis and was considered the personification of the hysterical uterus itself. Analysis. In the article, the meaning of the serpentine composition is considered in the comparative analysis with other images on amulets. This is possible due to the presence of stereotypes and general principles in the construction of magical drawings applied to the amulets, as well as the general meaning that is associated with the functional purpose of the phylacteries. In different types of the images on amulets, semantic emphasis is placed on reproducing the desired action. For this, phylacteries were made and used, and magical texts, signs, images of saints, the Mother of God and even Christ himself were applied to the amulet. Results. The symbolism of the serpentine composition is revealed within the same sign system. The drawing combining a head (face) and wriggling snakes clearly represents the desired effect - the outcome, the flight of illnesses or the forces of the evil symbolized by reptiles from a person.
\end{abstract}

Key words: Byzantine Christianity, folk beliefs, amulets, phylacteries, hair-snakes.

Citation. Barabanov N.D. Hair-Snakes. To the Issue of the Semantics of Byzantine Phylacteries with "Hystera". Vestnik Volgogradskogo gosudarstvennogo universiteta. Seriya 4. Istoriya. Regionovedenie. Mezhdunarodnye otnosheniya [Science Journal of Volgograd State University. History. Area Studies. International Relations], 2019, vol. 24, no. 6, pp. 316-330. (in Russian). DOI: https://doi.org/10.15688/jvolsu4.2019.6.25

УДК 94“04/14”: 159.961 .44

Дата поступления статьи: 01.02.2019

ББК 63.3(0)4-7

Дата принятия статьи: 24.07.2019

\section{ВОЛОСЫ-ЗМЕИ. К ПРОБЛЕМЕ СЕМАНТИКИ ВИЗАНТИЙСКИХ ФИЛАКТЕРИЕВ С «ИСТЕРОЙ»}

\section{Николай Дмитриевич Барабанов}

Волгоградский государственный университет, г. Волгоград, Российская Федерация

\footnotetext{
Аннотация. Статья посвящена анализу конкретного типа византийских филактериев (амулетов), являющихся ярким проявлением народных верований, сочетающих в себе языческие, магические и христианские компоненты. Речь идет о так называемых «змеевиках» - подвесках с изображением головы с рептилиями вместо волос или просто в сочетании со змеями. На многих из них присутствует магическая надпись с упоминанием «истеры» (матки), под которой может пониматься как этот конкретный орган, так и разные
} 
вредоносные сущности. По этой причине существует проблема соотнесения изображения и магической надписи. Но в статье предпринимается попытка интерпретации змеевидной композиции в контексте ее функционального предназначения. В историографии представлено множество мнений о том, что могли представлять изображения на данном типе памятников. В разное время исследователи видели в образе головы со змеями Медузу Горгону, дракона-сатану, русскую Афродиту - богиню Ладу, Абрасакса, Софию офитов, медного змия Моисеева, Еву и дьявола, семиглавого змия и семь смертных грехов, сестер-лихорадок, дракона из Апокалипсиса, змея Эскулапа, трансформировавшегося в сатану. Кроме того, композицию признавали «портретом» демона и его козней, возводили к образу Хнубиса и считали персонификацией самой истерыматки. В статье смысл змеевидной композиции рассматривается в сопоставительном анализе с другими изображениями на амулетах. Это возможно благодаря наличию стереотипов и общих принципов в построении магических рисунков, наносившихся на обереги, а также общего смысла, который связан с функциональным предназначением филактериев. В разных видах изображений на амулетах смысловой акцент сделан на воспроизведении желаемого действия. Ради него изготавливались и употреблялись филактерии. Ради него на амулет наносились магические тексты, знаки, образы святых, Богоматери и даже самого Христа. Символизм змеевидной композиции раскрывается в пределах этой же знаковой системы. Рисунок, сочетающий голову (лицо) и извивающихся змей, наглядно представляет желаемый эффект - исход, бегство недугов или сил зла, символизируемых рептилиями, из человека.

Ключевые слова: византийское христианство, народные верования, амулеты, филактерии, волосы-змеи.

Цитирование. Барабанов Н. Д. Волосы-змеи. К проблеме семантики византийских филактериев с «истерой» // Вестник Волгоградского государственного университета. Серия 4, История. Регионоведение. Международные отношения. - 2019. - Т. 24, № 6. - C. 316-330. - DOI: https://doi.org/10.15688/jvolsu4.2019.6.25

Введение. Хорошо известно, что употребление амулетов - универсальное явление для всех народов, независимо как от стадии развития, так и от специфики господствующих представлений об отношениях людей с миром сверхъестественного. Со времен глубокой архаики в сознании представителей разных страт общества существовала убежденность в том, что отдельные созданные человеком предметы или природные объекты обладают особыми магическими свойствами. В средневековом обществе в процессе сложного взаимодействия с христианством амулеты сохранили важное место в религиозной жизни, особенно в арсенале борьбы со злом в различных его вариантах. Защита от действия злых духов, колдовства, болезней, сглаза, внезапных бедствий и того, что представляет угрозу для жизни и материального благополучия, осуществлялась с их помощью. Фонд средств, использовавшихся с целью защиты, практически безграничен. В нем находится множество предметов живой и неживой природы, надписи на всевозможных материалах, компоненты религиозных культов, специально изготавливаемые подвески разных типов. Об одном из вариантов специально изготавливаемых подвесок византийского времени идет речь в данной статье.

Византийские амулеты заслуживают особого рассмотрения в рамках изучаемой темы, несмотря на значительное количество посвященных им исследований. Многие специалисты, публиковавшие и анализировавшие филактерии, видели в них памятники мелкой пластики, нуждавшиеся в интерпретации изображений и надписей. Разумеется, это необходимый и важный этап изучения данной группы источников. Однако не менее важно филактерии и связанные с ними представления исследовать в контексте и в структуре религиозности византийцев. Исследовать не как символ «двоеверия», а как функцию религиозности, как узел, в котором сплетены многие компоненты религиозной картины мира. Демонология присутствует здесь в аспекте представлений о нечистой силе, против которой действуют амулеты. Взгляд на мир божественный раскрывается с точки зрения практического употребления изображений святых или небесных сил в апотропеических целях. Антропологические и медицинские воззрения присутствуют в проблеме истеры как внутреннего органа, поражаемого недугом или демоном. Магия, частью которой является сам феномен филактериев, раскрывается в таинственных знаках, молитвах и заговорных формулах, нанесенных на оберег. Среди амулетов - подвесок в данной работе в центр внимания поставлены наделенные глубокой семантикой объекты, несущие на себе изобра- 


\section{ВИЗАНТИЙСКОЕ ПРАВОСЛАВИЕ}

жение головы в сочетании со змеями. В последнее время их чаще всего именуют филактериями с «истерой» или с «мотивом истеры». В качестве источников выступят сами амулеты. В настоящее время опубликовано 62 памятника, из которых 26 содержат змеевидную композицию в сочетании с магической надписью, а 36 - только изображение [16, p. 42]. В приложении к статье представлены фото нескольких амулетов данного типа, взятые, главным образом, из работы Д. Спайера [26]. Кроме того, использованы некоторые тексты, содержание которых позволяет понять связанные с филактериями представления. В используемой в работе методологии следует особо отметить историко - генетический метод.

Методы. В обширной научной литературе, посвященной византийским амулетам, присутствует несколько работ, в которых в той или иной мере представлена история изучения этих памятников $[16 ; 26 ; 6]$, что избавляет от необходимости заново реконструировать весь процесс накопления знаний и мнений о них. В рамках поставленной задачи в дальнейшем в историографическом аспекте внимание будет сосредоточено, прежде всего, на развитии представлений о том, что могла означать змеевидная композиция или «истера».

Анализ. Научный интерес к изучению и коллекционированию оберегов разных типов зародился в Европе период позднего Ренессанса. Однако можно без преувеличения констатировать, что глубокое и последовательное осмысление феномена христианских амулетов было инициировано в России, благодаря находке в 1821 г. на реке Белоус под Черниговом знаменитой «черниговской гривны»золотого филактерия, интерпретация которого породила множество мнений [6, с. 12-13]. Памятник принадлежал к тому типу подвесок, в которых сочетались христианские и «языческие» образы и надписи. Через некоторое время, благодаря изображению на одной из сторон человеческой головы в окружении змей, они получили наименование «змеевики». Среди скороспелых и поверхностных суждений, высказанных на этапе первоначального знакомства с темой, в то время выделялась точка зрения киевского митрополита Евгения (Болховитинова), связавшего памятник с традицией изготовления амулетов, идущей от гностиков и укоренившейся, не смотря на противодействие церкви, в народной среде [3, с. 121-123].

После фазы накопления эмпирического материала - разумею, результаты археологических изысканий и публикаций памятников из музейных фондов и частных собраний, всплеск интереса к теме наблюдался на исходе XIX столетия. И.И. Толстой, рассмотрев тридцать три известных ему змеевика, связал содержание заклинательной надписи и изображения головы и клубка змей с текстами Апокалипсиса [12, с. 399, 404]. Исследователь считал, что в этих амулетах отразился страх верующих людей перед грядущими бедствиями, наступление которых ожидалось со дня на день. Кроме того, он считал, что змеевики использовались, прежде всего, как средство от болезней и ран [12, с. 406-407]. Н. Петров, сосредоточив внимание на интерпретации изображения на одной из сторон филактерия человеческой головы, окруженной змеями, предложил свое объяснение, которое вышло за рамки узкого сюжета, и коснулось проблемы происхождения и предназначения амулетов. По его мнению, змеевики генетически связаны с культом римского бога врачевания Эскулапа, одним из центров почитания которого был Пергам [8, с. 19-20]. Атрибутом божества являлся жезл, обвитый змеей он то и мог стать прототипом змеиного гнезда на изучаемых памятниках. В христианское время змей Эскулапа отождествился с Сатаной, престол которого, согласно Апокалипсису (2:12-13), находился в Пергаме. Христианизация сюжета привела к тому, что постепенно перестали обращаться за помощью к змею - Эскулапу, а призывали Бога и святых его, чтобы они оградили и защитили молящегося от змея - дьявола.

Г. Шлюмберже, посвятил теме большую статью, представив в первую очередь амулеты из собственного собрания [25]. В общей сложности исследователь каталогизировал 29 памятников. По смыслу изображений часть из них он отнес к плодам деятельности гностических сект, а формы других возвел к языческим суевериям. Однако в итоге он отметил, что все амулеты являются византийскими, азиатского или сирийского происхождения $[25$, p. $88,91,93]$. 
Заметным шагом вперед в деле изучения византийских филактериев стали две статьи М.И. Соколова, не потерявшие научного значения до сих пор $[10 ; 11]$. Поскольку в то время еще оставались сомнения в предназначении змеевиков, исследователь высказал убеждение в том, что они суть не что иное, как предохранительные наузы, амулеты - филактерии, употребляемые против болезней [10, c. 340]. Что касается объяснения изображений и надписей, то в качестве исходного материала он использовал легенды, молитвы и заклинания, которые в греческой и славянской письменности связаны с именем св. Сисиния, с архангелом Михаилом и некоторыми другими святыми. Кроме того, исследователь выявил зависимость амулетов от магического трактата «Завещание Соломона» (Testamentum Solomonis), ставшим основой для заклинательных молитв. Анализируя эти тексты, М.И. Соколов сделал важные наблюдения по византийской демонологии. Так он связал изображение на змеевиках женской головы или фигуры, окруженной змеями, с представлениями о похищавшем детей злом демоническом существе, победу над которым одержал св. Сисиний. Змеи же, исходящие из головы, по его мнению, символически представляют многообразные «козни» дьявола [10, с. 343-344]. Борьба с этим представителем нечистой силы, по мысли исследователя, состояла в употреблении нескольких средств. Среди них: 1) имена демона, которых обычно насчитывается 12 или 12 с половиной; 2) имена ангелов или святых, поймавших демона и отобравших у него имена и взявших с него клятву; 3 ) имена как демона, так и ангелов и святых; 4) вообще молитва против дьявола, содержащая рассказ о поимке его ангелами или святыми и о его «кознях». При этом прогоняющую силу имеет как чтение молитвы, так и простая запись ее и ношение с собой в качестве филактерия, амулета, науза [10, с. 349]. Содержание магической надписи, упоминающей «истеру», исследователь также интерпретировал в связи с верованием в демоническое существо, полагая, что «истера» - одно из его имен. Упомянутые наблюдения М.И. Соколов развил во второй статье, которую целиком посвятил анализу заклинательной надписи на основе сопоставления греческих и славянских магичес- ких текстов. По его мнению, греческой «истере» у славян соответствовало понятие «дна», обозначавшее демоническое существо женского рода, причинявшее человеку мучительные болезни [11, с. 136]. Поскольку славянские тексты заклинаний и молитв восходят к греческим оригиналам, содержание которых стало известно через переводы, исследователь допустил возможность взаимной экстраполяции соответствующих компонентов верований и на этой основе пришел к выводу, что слово «дна» могло иметь несколько значений, а именно: 1) матка, чрево, желудок; 2) болезнь как этих частей тела, так и вообще тяжелая внутренняя болезнь; 3) демоническое существо, причиняющее эту болезнь [11, с. 138]. Рассмотрев некоторые другие недуги и магические способы борьбы с ними, М.И. Соколов отметил, что в молитвах и заклинаниях болезни представляются как проявления бесовской силы или как сами бесы, в образах которых эти болезни проявляются. Недуги могли представляться как отдельные демонические существа, или как дети демона, или как разные его козни. Прогоняются же болезни силою божества, ангелов, святых, а также при помощи заклинаний, действующих не только произнесением, но лишь написанием на каком-либо материале [11, с. 174]. Выводы исследователя в значительной мере прояснили суть мыслительных процессов, представлений и стереотипов сознания, которые были связаны с употреблением филактериев как в Византии, так и в средневековом славянском мире.

Анализ понятия «истера» в те же годы был предпринят В. Дрекслером на основе сопоставления греческой, немецкой и итальянской заговорных традиций [21, S. 594-608]. Исследователь остановился на самом распространенном смысле слова - «матка» [21, S. 598], но при этом показал широкую гамму представлений, которые были с ним связаны. В частности, принадлежность в народных воззрениях этого постоянно нуждающегося в усмирении органа как женщинам, так мужчинам, что было характерно не только для византийской истеры, но и для немецкой Gebärmutter [21, S. 602-603].

Граф А.С. Уваров, который был вдохновлен на изучение филактериев находкой «чер- 


\section{ВИЗАНТИЙСКОЕ ПРАВОСЛАВИЕ}

ниговской гривны», рассмотрел тему в широком хронологическом диапазоне, начиная с раннехристианского времени [13]. Исследователь связал распространение амулетов в среде христиан с деятельностью гностических сект, отметив, что в то время всякая античная медаль или гемма годились в качестве апотропея [13, с. 242]. Церковь, негативно реагируя на сохранение языческих традиций, для борьбы с ними ввела в употребление привески, называвшиеся на западе Agnus dei, поскольку они несли на себе изображение агнца. Следует отметить, что с того времени количество собственно христианских филактериев стало быстро возрастать. В качестве таковых стали использовать изображения рыб, сопровождаемые надписями и таинственными цифрами, подвески с именем или монограммой Христа, пластинки с текстами заклинаний. С точки зрения формы, изготовлялись они по древним образцам [13, с. 244]. А.С. Уваров отметил, что даже кресты, которые обычно не имели значения амулетов, могли сопровождаться заклинательными надписями или символическими изображениями нечистой силы, что придавало им охраняющую силу и превращало в филактерии [13, с. 245-246]. Изучая иконографию нечистой силы, в частности, разбирая причину появления змеиных сюжетов на амулетах, исследователь объяснил их следующими логическими импульсами в сознании людей того времени. В период продолжения борьбы с гностической ересью змей должен был представлять самого Сатану, а человеческая природа должна была слиться со змеиной. В этот момент влияние «воспоминаний об античном искусстве» дало подходящий образ головы Горгоны или Медузы, представлявшей тип человека-змеи. Тем самым А.С. Уваров подчеркнул, что змеиный сюжет на амулетах не был простым подражанием античным горгонам, а являлся элементом развития христианской демонологии [13, с. 251].

Рассматривая предназначение и символику христианских наузов, как византийских, так и русских, исследователь пришел к выводу, что металлические амулеты представляли символически победу над дьяволом или всяким злом, происходящим от него. В частности, подразумевались победы архангела
Михаила, Богородицы, св. Никиты, св. Феодора Тирона, имена которых на том же основании включались в заклинания и молитвы $[13$, с. 253-254].

Изучение амулетов на русских материалах было продолжено в советский период, свидетельством чему стала обобщающая работа А.С. Орлова [7]. Однако автор уделил внимание не семантике изображений, а описанию и классификации 116 змеевиков, хранящихся в Историческом музее. Взяв за основу вариации змеевидной композиции [7, c. 13-26], исследователь выделил восемь типов памятников, не углубляясь в детали их семантики.

Известный историк византийской церкви В. Лоран также уделил внимание филактериям с «истерой». В отличие от А.С. Орлова, он не придавал особого значения внешнему виду и числу змей в соответствующей композиции. По этой причине исследователь сосредоточил внимание на классификации типов и сопоставлении различных формул заговорной надписи [24]. В первой части статьи, разбирая варианты легенд на амулетах, он отметил, что византийцы - носители филактериев не считали их употребление чем-то предосудительным. Вместе с тем, они полагали нелишним привлечение помощи Всевышнего, что отразилось в инвокациях, выражавших православную набожность [24, р. 302-303]. Анализируя содержание магического заклинания, направленного против истеры, В. Лоран отметил, что оно содержит приказ истере успокоиться подобно змее, стать тихой подобно морю, смирной и кроткой, как овца и кошка. В этом перечне он заметил иерархию, в рамках которой заговор развивается по нисходящей линии [24, p. 305-306]. Во второй части статьи исследователь опубликовал шесть амулетов, отчасти прежде совсем неизвестных, отчасти известных мало и послуживших ему основой для интерпретаций. Завершили работу наблюдения по поводу содержания понятия «истера», которое автор считал развивавшимся во времени и способным означать больной орган (матку), различные заболевания низа живота, одновременный беспорядок всего организма (истерию) и, как остаток гностической космогонии, принцип оплодотворения [24, p. 314-315]. 
А.А. Барб в нескольких работах обращался к проблеме представлений об «истере», исследуя амулеты, геммы, вотивы, гностические тексты в контексте глубоких традиций, уходящих корнями в древний Ближний Восток, Египет, Грецию и Рим [14]. Византийские филактерии этого типа он связал с образами демона Авизу из «Завещания Соломона» и с Горгоной, считая, что архаические концепции устойчиво сохранялись в народной традиции [14, p. 211].

В отечественной историографии второй половины минувшего столетия темой амулетов продолжали интересоваться специалисты по византийскому искусству. В частности, Г.К. Вагнер на древнерусских материалах предпринял не слишком убедительную попытку «реабилитировать» змеевидную композицию на филактериях, полагая, что она не обязательно должна изображать демона [2].

Однако наибольшее внимание проблеме, как с точки зрения анализа конкретных памятников, так и в теоретическом аспекте, уделила В.Н. Залесская [28; 5]. В вопросе об интерпретации изображений она согласилась с выводами М.И. Соколова, но предприняла попытку существенно развить их в направлении поиска датирующих признаков. Отсутствие датировок или слишком большой разброс хронологических вех были справедливо отнесены ею к недостаткам современной историографии. Анализируя змеевидную композицию на амулетах, исследовательница пришла к мысли о том, что число изображенных змей - это важная деталь, позволяющая поставить вопрос о различных источниках того или другого типа филактериев [28, p. 244-245]. Обереги с двенадцатью головами змей она связала с обозначением многоименного демона, представленного в византийских заклинательных молитвах, популярных в XII веке. Подвески этого типа отнесены ею к XIXII векам. Амулеты с изображением семи змеиных голов, по мнению В.Н. Залесской, обозначают демона, который фигурирует в Testamentum Solomonis, магическом тексте, имевшем широкую известность в IV-VII вв., а позже забытом. Филактерии с заговором против истеры исследовательница датировала периодом X-XI вв. [28, p. 247]. Участвуя в дискуссии по поводу «суздальского змееви- ка», исследовательница обосновала интересное предположение, высказанное еще А.С. Орловым, и состоящее в том, что амулеты могли изготавливаться в Византии по русскому заказу [5, с. 187]. Следует отметить, что мнения исследователей существенно усложняли изучаемую проблему, ставя вопрос о восприятии и понимании филактериев с «мотивом истеры» в иной культурной среде.

А. Грабар, помимо описания небольшой группы византийских амулетов, ставил перед собой задачу «привлечь внимание к объекту суеверного действия, на которое отвечают эти филактерии, и к роли, отведенной в них образу» [22, p. 531]. Среди оберегов, рассмотренных автором, оказались подвески и изображения разных типов. В связи с этим особый интерес представляют обобщающие наблюдения исследователя. Анализируя роль образов, он сравнил их употребление с понятиями «гомеопатия» и «аллопатия» [22, p. 537]. Гомеопатическое использование изображения, по его мнению, основано на стремлении напомнить, как в случае с ефесскими отроками, предшествующий пример милости Христа, возобновления которой желали. Аллопатическая манера свидетельствует об использовании образа для того, чтобы изображать личности или объекты (Богоматерь, святых, крест), которые своим действием несут спасение, исцеление, освобождение от всех зол. Что касается монстра со змеями, то его А. Грабар признал изображением дьяволицы, известной по многим апокрифам. Побежденная и плененная святыми св. Сисиннием или другими, она была поставлена на службу христианам, носившим на себе филактерий с ее «портретом». Тем самым присутствие прирученного демонического существа становилось благоприятным.

Выбор аллопатических изображений, по мысли автора, был продиктован теми же соображениями, как и в случае с византийскими печатями - другими объектами, на которых представляли персонажей, способных обеспечить покровительство. Образ Богоматери, сцены Крещения и Распятия, крест, св. Михаил и святые воины, знаменовали победу над демоном, напоминали о могуществе защитников и взывали к их помощи [22, p. 538-539]. 


\section{ВИЗАНТИЙСКОЕ ПРАВОСЛАВИЕ}

Ж. Бланков, используя в основном древнерусские материалы, посвятил теме амулетов серию статей $[17 ; 18 ; 19 ; 20]$. Рассматривая употребляемые на Руси филактерии в обширном контексте оберегов античного и средневекового времени, автор отнес их к числу курьезных памятников так называемого «двоеверия» - смеси языческих и христианских верований $[18$, с. $203 ; 17]$ и даже счел символом этого явления. Тем самым исследователь присоединился к широко известному мнению, представленному в большинстве российских публикаций советского периода. Касаясь интерпретации одного из популярнейших образов, изображавшихся на амулетах, головы в окружении змей, Ж. Бланков неоднократно и твердо высказался в пользу понимания его в связи с сохраненным Византией античным мифом о Медузе Горгоне, голова которой обладала апотропеическими свойствами.

Необходимо отметить, что древнерусские змеевики в то время продолжали привлекать внимание многих исследователей. Б.А. Рыбаков, считая амулеты «прекрасным примером христианско-языческого двоеверия», связывал их употребление с княжеско-боярскими кругами [9, с. 653]. В змеевидных композициях он усматривал два восходящих к античности сюжета: голову Медузы и змееногую прародительницу скифов [9, с. 653-656].

Лучший до сих пор обзор проблематики, связанной с древнерусскими амулетами-змеевиками был сделан Т.В. Николаевой и А.В. Чернецовым [6]. Исследователи показали сложный синкретический характер того феномена, который по традиции обозначается понятием «двоеверие», уделив большое внимание компоненту, принесенному на Русь из Византии в рамках единого культурного потока с церковной ортодоксией. Изучая иконографические варианты змеевидной композиции на древнерусских змеевиках, авторы неизбежно затронули некоторые аспекты византийской демонологии. В частности, по их мнению, изображения человеческой головы в окружении змей в византийское время утрачивают связь с мифом о Медузе Горгоне и ассоциируются с персонажем под названием «истера». Образы демонических существ сближаются [6, с. 34]. Отмечу еще одно наблюдение авторов. Полагая, что голова Медузы в ан- тичное время, как и позднейшая змеевидная композиция, имели характер оберега от болезней, исследователи сочли, что ранние византийские амулеты-змеевики бытовали в «малообразованной среде» [6, с. 33].

Следует отметить, что в то время как в отечественной историографии относительно одного из важнейших сюжетов темы - интерпретации змеевидной композиции, преобладало мнение, связавшее ее с Медузой Горгоной, за рубежом продолжался поиск иконографических истоков изображения. Г. Вайкен, к примеру, представил точку зрения, состоящую в том, что голова со змеями вместо волос восходит к фигуре не слишком известного египетского божества Хнубиса [27]. На магических геммах римского времени Хнубис почти всегда принимал вид змеи с лучистой головой льва. Что касается его специализации, то из тридцати шести астрологических деканов, которые, по представлениям египтян, контролировали человеческое тело, к нему имели отношение заведовавшие областью желудка и матки. Изучая памятники ранневизантийской торевтики, происходящие из Египта и имеющие апотропеическое значение, Г. Вайкен предположил, что со временем манера изображения Хнубиса эволюционировала, приняв облик человеческого лица, а лучи трансформировались в змей $[27$, p. 75-76]. Экстравагантная идея исследователя, подвергнутая позже не раз разрушительной критике, может, тем не менее, иметь некоторое отношение к диалектам верований, связанных с употреблением амулетов данного типа.

Накопление эмпирического материала и большой опыт его осмысления под разными углами зрения дали основание для появления обобщающей работы, посвященной византийским филактериям. До сих пор статья Д. Спайера остается единственным трудом, претендующим на охват важнейших аспектов темы и содержащим каталог всех опубликованных к началу 90-х гг. византийских амулетов [26]. Исследователь рассмотрел различные варианты надписей на оберегах, а также сложный вопрос о датировке подвесок. На основе стилевых особенностей и археологического контекста он отнес значительную часть из ныне известных памятников к периоду X-XII вв. [26, p. 31-33]. Наибольшее место в работе за- 
нимает раздел «Иконография», содержание которого значительно шире изучаемого сюжета [26, p. 33-44]. Интерпретацию изображений на амулетах автор сопроводил основательным очерком ближневосточной, античной и средневековой демонологии, в котором особое внимание уделено образам нечистой силы женского происхождения. Если ранневизантийские филактерии могли быть связаны с традицией, идущей от верований в Лилит, Авизу, Гилу, то на средневековых оберегах более постоянный мотив представлен в виде змеевидной композиции. В процессе ее анализа автор подверг критике точки зрения В.Н. Залесской и Г. Вайкена. Отвергнув связь медузоподобного существа с Testamentum Solomonis и, тем более, с Хнубисом, он счел, что речь должна идти об изображении истеры. Собственное мнение Д. Спайер выразил в следующих словах: «средневековые византийские амулеты происходят от параллельной, но особой магической традиции, базирующейся более на медицинском, чем магическом фольклоре, кото-

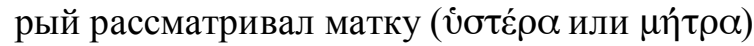
как независимое творение, живущее в человеческом теле» [26, р. 42]. Развивая мысль, автор отметил, что средневековые амулеты могут быть твердо помещены в длительную традицию верования в одухотворенную матку, которая нуждается в успокоении. В соответствии с этими верованиями матка показывает некое демоноподобное поведение, но она не может быть приравнена к Авизу-Гилу демону [26, p. 44]. Логическим продолжением сюжета явилось обращение исследователя к заговорной формуле против истеры. Поиск ее прототипов привел к некоторым элементам магической практики V в., но в Византии, по мнению автора, заговор стал популярен не ранее X в., когда возрос интерес к текстам, в которые формула была инкорпорирована [26, p. 50-51].

Целью К. Горничковой было изучение византийских оберегов на основе антропологического подхода и с помощью семиотики [23]. Автором выделены два аспекта темы: понимание амулетов как посредников силы святого, и персонификация болезни или человеческого органа с последующей трансформацией этого больного органа в чисто демоническое начало [23, р. 241]. Особое внима- ние уделено той группе амулетов, которые совмещали два вида полученной ими энергии магической, сохранявшей элементы языческой традиции, и чудесной, являющейся христианским изобретением. Именно такого рода объекты играли важную роль в практической части народной религии. Второй аспект темы связан с изучением эволюции понятия «истера», представления о которой, по мнению автора, в средневековое время прошли путь от персонификации болезни до злого демонического начала [23, p. 243-245]. По мнению автоpa, постепенно в народном воображении истера становится полу-женской, полу-животной персонификацией нечистых духов, не простым живым существом, а демоном. В средневизантийский период истера стала восприниматься не только как персона или злой демон, но как некое явление, которое может жить вне тела и входить в него. В это время истера связалась с материнством и приняла вид Медузы Горгоны, персонифицируясь как вредящий женский демон.

Автор этих строк в свое время также уделил внимание амулетам данного типа, поставив в центр исследования развитие представлений об истере в контексте проблемы народных верований в Византии [1]. Помимо самих оберегов в статье рассмотрено множество письменных свидетельств античного и византийского времени, в которых она упоминается. Анализ этих материалов, а также всей историографической традиции привел к ряду выводов. Во-первых, не стоит излишне архаизировать образ изучаемого явления в византийское время. Тем более, сближать его с мифом о Медузе Горгоне. Для этого нет достаточных оснований. Как нет их и для того, чтобы приписать византийцам архаичное верование в матку как живое существо, обитающее внутри человеческого тела. Во-вторых, противопоставление двух традиций представлений об истере - ученой медицинской и народной также не обосновано. Они сосуществовали, в большей мере дополняя друг друга, нежели пребывая в антагонизме. В-третьих, амулеты с заклинанием истеры и змеевидной композицией относятся к числу тех, которые имели медицинскую специализацию и были направлены на борьбу с женскими болезнями - первоначально это явно женские 


\section{ВИЗАНТИЙСКОЕ ПРАВОСЛАВИЕ}

амулеты. Со временем сфера применения таких филактериев и заклинаний расширилась. Вероятно, это связано с тем, что имя «истера» постепенно закрепилось также и за духом болезни, проникавшим в тело человека [1].

В недавнее время фонд амулетов с данным мотивом удостоился диссертационного исследования. Речь о работе Х. Бьёрклунд, которая была защищена в университете Хельсинки в 2017 г. [15; 16]. Автором поставлена задача изучения медицинско-магических амулетов, имеющих отношение к матке и защите женщин и детей в контексте традиции магических текстов, мифологии и народных сказаний о демонах, убивающих новорожденных детей и рожениц $[16$, p. 7]. Хронологические рамки работы широки - от архаической Греции (VI-VII вв. до н. э.) до XV в. н. э. Географические рубежи также обширны - Сирия, Палестина, Египет, Греция, Малая Азия. В амулетах с истерой Х. Бьёрклунд увидела синкретический образ. С одной стороны, в них присутствовало народное верование в «блуждающую матку», которую признавали независимым существом, способным двигаться в теле и причинять болезни. С другой стороны, имелось верование в женских демонов, убивающих новорожденных детей и беременных женщин.

Итак, напомню, что нас сейчас интересует не весь комплекс представлений об истере и связанных с ней амулетах, а только визуальный образ - голова в разных сочетаниях со змеями. В историографии, как было отмечено, накопилось множество интерпретаций этого изображения. В нем видели еще с XIX в. Медузу Горгону, дракона-сатану, русскую Афродиту - богиню Ладу, Абрасакса, Софию офитов, медного змия Моисеева, Еву и дьявола, семиглавого змия и семь смертных грехов, сестер-лихорадок, дракона из Апокалипсиса, змея Эскулапа, трансформировавшегося в сатану. Кроме того, композицию признавали «портретом» демона и его козней, возводили к образу Хнубиса и считали персонификацией самой истеры-матки.

Обилие мнений не означает, что уже не существует иных возможностей интерпретации данных объектов. Смысл змеевидной композиции может быть понят в сопоставительном анализе с другими изображениями на амулетах. Это возможно, благодаря наличию стереотипов и общих принципов в построении магических рисунков, наносившихся на обереги, а также общего смысла, который связан с функциональным предназначением филактериев. И здесь необходимо подчеркнуть, что в апотропеях всех типов общим и главным является действие, содержание которого заложено в магических текстах и образах.

В случае с византийскими филактериями речь, что вполне естественно, должна идти о защитном действии, направленном против различных видов зла. Так на широко известных амулетах с фигурой святого всадника, которого понимают то как царя Соломона, то как св. Сисинния, герой поражает копьем лежащую на земле женскую фигуру, символизирующую демоническое начало, возможно, нечистого духа Гилу. Смысловой акцент изображения состоит в показе действия, в котором зло побеждено и лишается своей вредоносной силы. Рисунок на амулете по существу превращается в иллюстрацию желаемого эффекта. Таковым является обезвреживание зла, изгнание или отвращение его от человека, обладающего филактерием. Магическая результативность изображения предопределена воспроизведением архетипа того самого события и действия, благодаря которому зло было когда-то побеждено. Другой вариант амулетов с Соломоном в качестве главного персонажа представляет его с кнутом в руках. Библейский царь избивает демона в женском облике, демонстрируя тем самым свою власть над нечистой силой. Композиция, с одной стороны, пиктографически выражает основную идею апокрифа «Завещание Соломона», а с другой стороны, представляет желаемый результат - изгнание беса, лишение его вредоносной силы.

Также хорошо известен гематитовый амулет с воспроизведением одного из чудес - сцены исцеления Христом кровоточивой женщины. Он не только отсылает к евангельскому сюжету как к архетипу и прецеденту. Действие изображения состояло в представлении самого момента совершения чудесного избавления от недуга. Повторения этого события жаждали обладатели таких амулетов. Анализ содержания изображений на филактериях заставляет вспомнить архитектонику молитв, как канонических, так и апокрифических. Особенно те из них, которые употребляются по конкретно- 
му поводу, непременно включают в композицию напоминание об уже совершенном адресатом молитвы чуде, повторения которого испрашивает молящийся. Очевидно, что при создании оберегов рассмотренных типов использовался тот же принцип общения с вышними силами, точнее, способ воздействия на них. Семантика изображений в функциональном аспекте аналогична семантике слов.

Еще один тип филактериев связан с универсальным и широко распространенным в греческой среде верованием в силу дурного глаза, предполагавшим использование против него специальных оберегов. Большинство из них несли на себе изображение глаза, поражаемого кинжалами или терзаемого хищными зверями. В таком рисунке также присутствует действие - «выкалывание» ока, а также желаемый итог - недопущение или снятие порчи, являющейся следствием контакта с его вредоносным взглядом.

Результаты. Во всех перечисленных видах изображений смысловой акцент сделан на воспроизведении желаемого действия. Ради него изготавливались и употреблялись филактерии. Ради него на амулет наносились магические тексты, знаки, образы святых, Богоматери и даже самого Христа. Символизм змеевидной композиции раскрывается в пределах этой же знаковой системы. Рисунок, сочетающий голову (лицо) и извивающихся змей, наглядно представляет желаемый эффект - исход, бегство недугов, символизируемых рептилиями, из человека. Символика змей в мифологии и магической традиции, в народных представлениях и демонологии, разумеется, значительно разнообразней. Однако в данном случае важны те коннотации образа змеи, которые утвердились в христианской картине мира. Достаточно напомнить, что общим местом в религиозном сознании византийцев было представление о том, что болезнь является следствием проникновения в человека нечистой силы. Следовательно, исцеление должно было состоять в изгнании демона или злого духа. Примерами такого рода врачевания наполнены жития святых. К примеру, только в житии святого Феодора Сикеота трижды упоминается исхождение змей из исцеляемых людей $[4$, c. $118,139,141]$. Особенно интересен в контексте изучаемой темы тот случай, когда недуг был изгнан из больного бедра через волос [4, с. 118]. Образ змеи мог стать персонификацией болезней, и это уже не раз было отмечено исследователями, видевшими в рептилиях трясавиц - лихорадок. Об этом же говорит то, что часто змеи на византийских амулетах изображены с ушами и даже гривами. Это позволяет интерпретировать змееобразных существ вовсе не как рептилий, а как персонификации недугов или того зла, которое причиняет человеку страдания, возможно, духа болезни. Амулет, как и заговор, не мог быть безадресным. По этой причине метафорическая персонификация была необходима для того, чтобы материализовать объект магической атаки. Итак, стоит подчеркнуть еще раз, змеевидная композиция наглядно представляет желаемое действие исход недугов или сил зла из пораженного ими человека. Некоторые из сохранившихся памятников прямо говорят об этом, поскольку несут на себе магические надписи, содержащие императив $\varphi \varepsilon \tilde{v} \gamma \varepsilon$ (беги!), повелевающий демонам удалиться от обладателя филактерия. Количество изображаемых на оберегах «змей» варьируется от четырех до двенадцати, но, к сожалению, состояние византийских источников не позволяет достоверно реконструировать этот компонент магической традиции. Возможно, в известной мере его раскрывают имевшие византийские корни славянские верования в существование двенадцати духов болезней, лихорадок, сестер-трясавиц, которых считали дочерьми царя Ирода.

В подавляющем большинстве амулетов данного типа в центре змеевидной композиции находится более или менее четкое изображение головы или лица. Очевидно, эти образы символизировали человека, который нуждался в исцелении и защите. Наличие филактериев с указанием имен владельцев не только подтверждает это, но и свидетельствует об индивидуальном характере изготовления и употребления оберегов. Таким образом, филактерии с «мотивом истеры» обретали вполне конкретный смысл. Изображение представляло одновременно желаемое действие и результат - исход недугов и/или сил зла из человека, что придавало амулету свойства метафизического оружия и доспеха. 


\section{ВИЗАНТИЙСКОЕ ПРАВОСЛАВИЕ}

\section{ПРИЛОЖЕНИЕ}

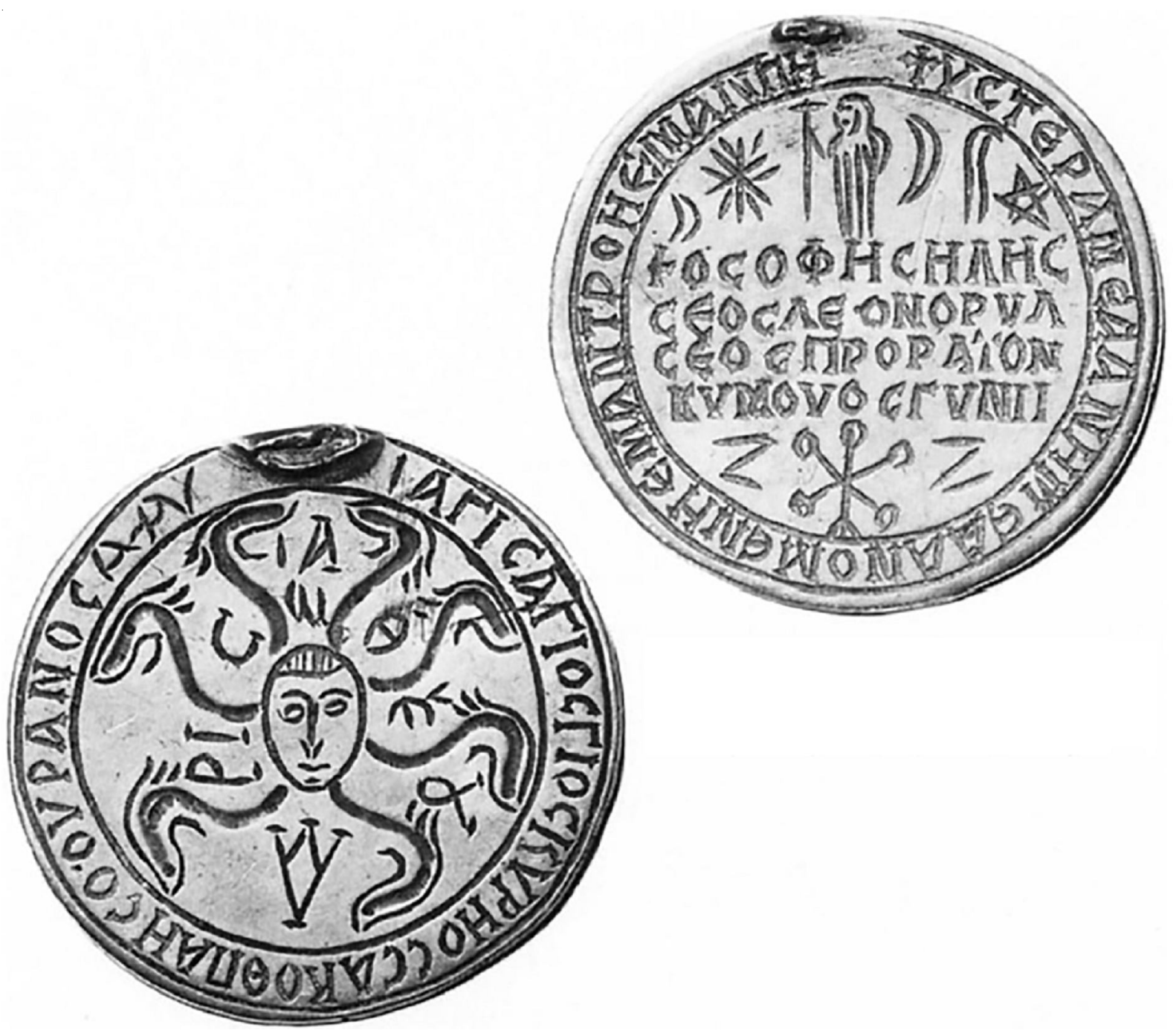

Рис. 1. Амулет из Музея коллекции Менил (г. Хьюстон, Техас, США), Малая Азия, VII-VIII вв., серебро, $d=4,5$ см (аверс и реверс) (источник: [13, pl. 3, по. 34])

Fig. 1. Amulet from the Menil Collection Museum (Houston, Texas, USA), Asia Minor, $7^{\text {th }}-8^{\text {th }} \mathrm{cc}$., silver, $d=4.5 \mathrm{~cm}$ (obverse and reverse) (source: [13, pl. 3, no. 34]) 


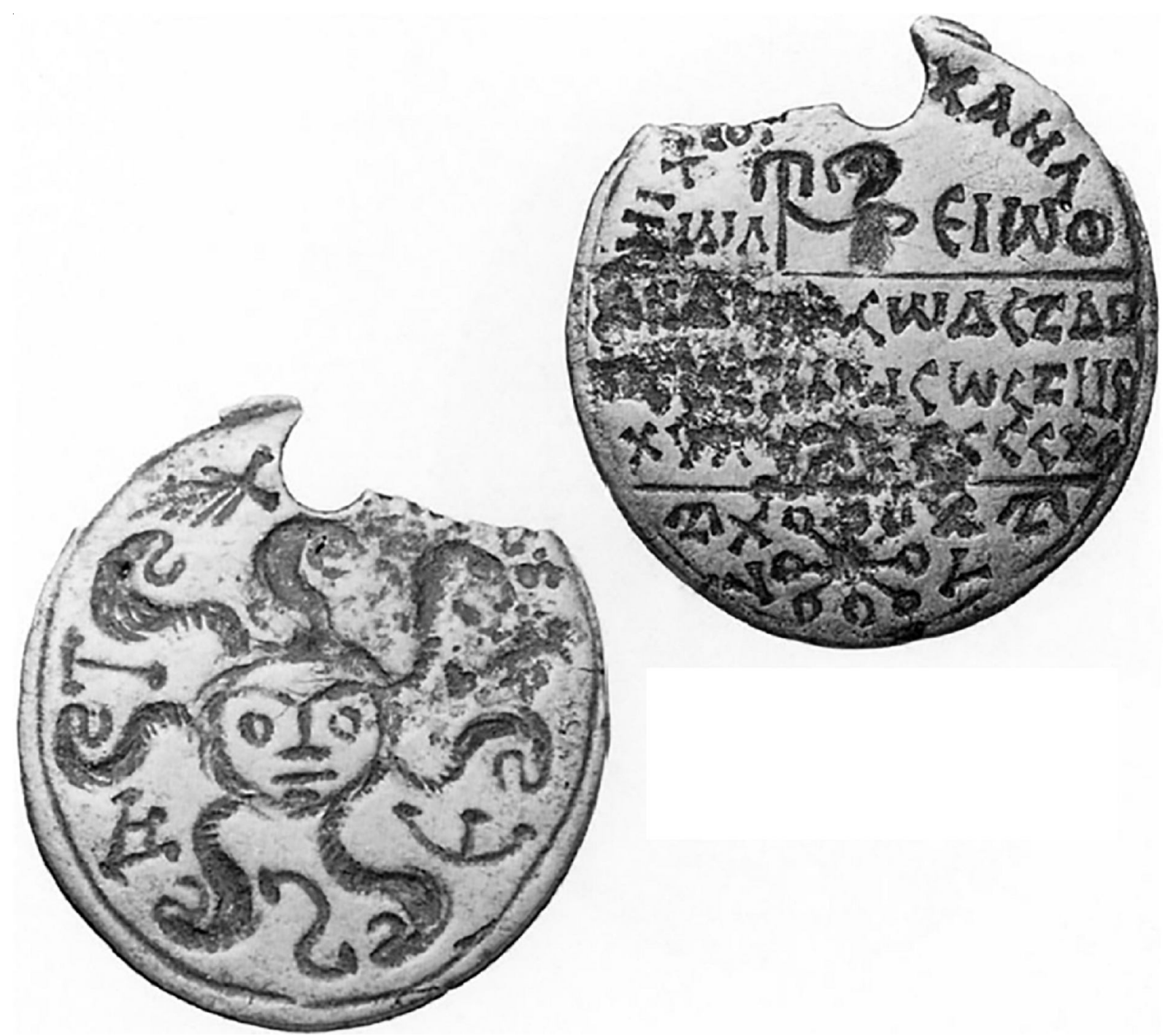

Рис. 2. Амулет из Эшмолеанского музея искусства и археологии (г. Оксфорд, Великобритания), бронза, $d=4,1$ см (аверс и реверс) (источник: [13, pl. 3, nо. 35])

Fig. 2. Amulet from the Ashmolean Museum of Art and Archaeology (Oxford, UK), bronze, $d=4.1 \mathrm{~cm}$ (obverse and reverse) (source: [13, pl. 3, no. 35]) 


\section{ВИЗАНТИЙСКОЕ ПРАВОСЛАВИЕ}
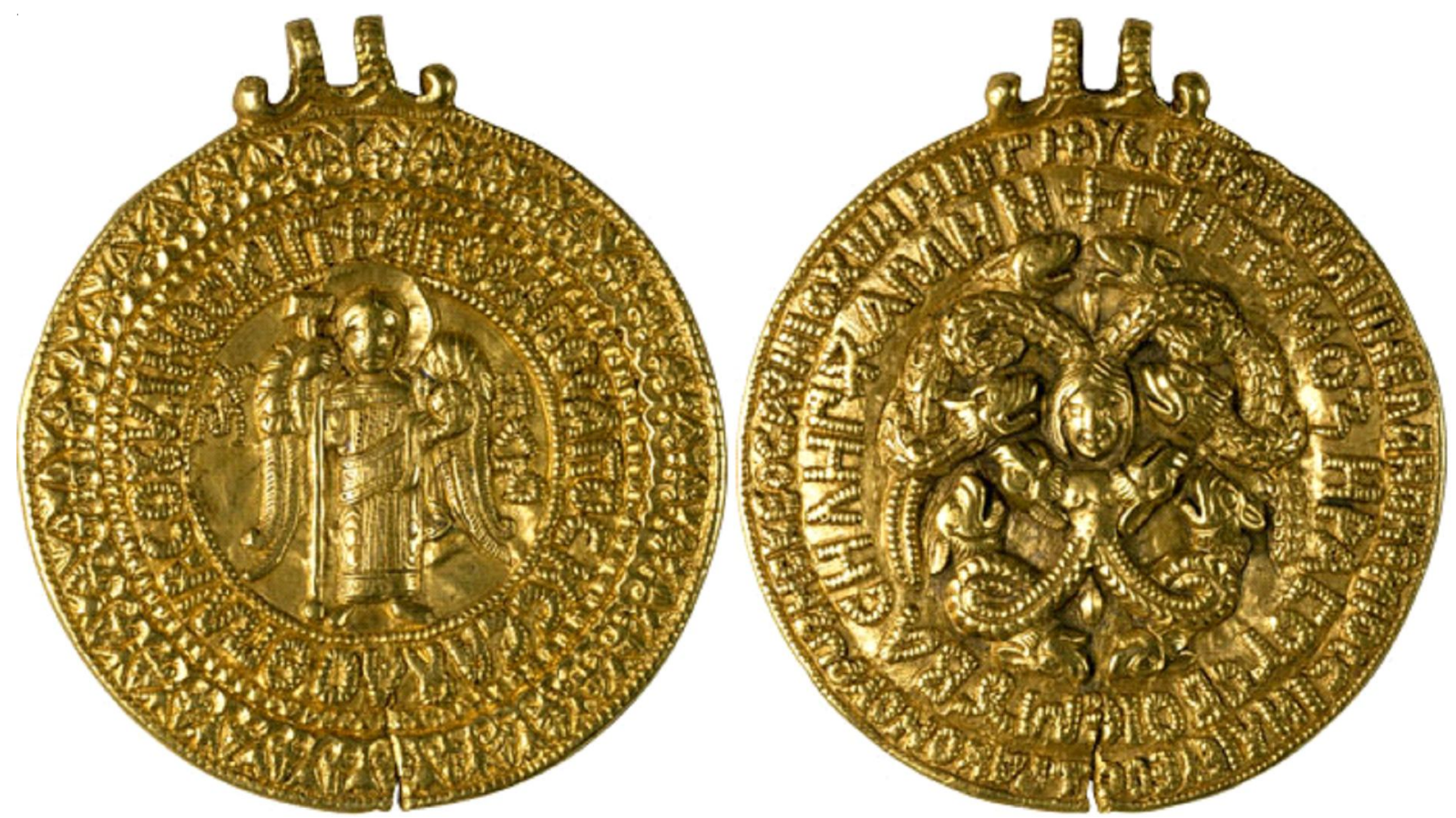

Рис. 3. Змеевик («Черниговская гривна») из Государственного Русского музея

(г. Санкт-Петербург, Российская Федерация), Чернигов, ХІ в., золото, чеканка, $d=7,8$ см (аверс и реверс)

Fig. 3. Serpentine ("Chernihiv hryvnia") from the State Russian Museum

(Saint Petersburg, Russian Federation), Chernigov, $11^{\text {th }} \mathrm{c}$. , gold, coinage, $d=7.8 \mathrm{~cm}$ (obverse and reverse) 


\section{REFERENCES}

1. Barabanov N.D. K istorii vizantiyskikh narodnykh verovaniy. Istera [To the History of Byzantine Folk Beliefs. Hystera]. Antichnaya drevnost i srednie veka, 2003, vol. 34, pp. 322-347.

2. Vagner G.K. O zmeevidnoy kompozitsii na drevnerusskikh amuletakh - zmeevikakh [On the Serpentine Composition on Old Russian Serpentine Amulets]. Kratkie soobshcheniya instituta arkheologii [Brief Communications of the Institute of Archaeology], 1961, vol. 85, pp. 26-30.

3. Evgeniy (Bolkhovitinov), metropolitan. Zamechaniya o chernigovskoy grivne [Notes About the Chernihiv Hryvnia]. Trudy i letopisi obshchestva istorii i drevnostey rossiyskikh pri Moskovskom universitete, 1833, vol. VI, pp. 121-123.

4. Afinogenov D.E., ed. Zhitie prepodobnogo Ottsa nashego Feodora, arkhimandrita Sikeonskogo, napisannoe Georgiem, uchenikom ego i igumenom toy zhe obiteli [Life of Our Venerable Father Theodore, Archimandrite of Sikeon, Written by George, His Disciple and Abbot of the Same Monastery]. Moscow, Indrik Publ., 2005. 183 p.

5. Zalesskaya V.N. K voprosu ob atributsii suzdalskogo zmeevika (v svyazi so statey A.V. Ryndinoy "Suzdalskiy zmeevik" [On the Issue of Attribution of the Suzdal Coil (In Connection with the Article by A.V. Ryndina "Suzdal Coil")]. Vizantiyskiy vremennik [Byzantina Xronika], 1974, vol. 36, pp. 184-189.

6. Nikolaeva T.V., Chernetsov A.V. Drevnerusskie amulety-zmeeviki [Old Russian Coil Amulets]. Moscow, Nauka Publ., 1991. 124 p.

7. Orlov A.S. Amulety "zmeeviki" Istoricheskogo muzeya [Amulets "Coils" of the Historical Museum]. Moscow, 1926. 55 p.

8. Petrov N. O proiskhozhdenii i znachenii tak nazyvaemykh zmeevikov [On the Origin and Significance of the So-Called Coils]. Sbornik snimkov $s$ predmetov drevnosti, nakhodyashchikhsya $v$ g. Kieve $v$ chastnykh rukakh [Collection of Photographs of Privately Owned Antiquities from Kiev]. Kiev, Tipografiya S.V. Kulzhenko, 1891, vol. 3-4, pp. 17-20.

9. Rybakov B.A. Yazychestvo Drevney Rusi [Paganism of Ancient Russia]. Moscow, Nauka Publ., $1987.221 \mathrm{p}$.

10. Sokolov M.I. Apokrificheskiy material dlya obyasneniya amuletov, nazyvaemykh zmeevikami [Apocryphal Material for Explaining Amulets Called Serpentines]. Zhurnal ministerstva narodnogo prosveshcheniya, 1889, vol. CCLXIII, no. 2 (June), pp. 339-368.

11. Sokolov M.I. Novyy material dlya obyasneniya amuletov, nazyvaemykh zmeevikami [New Material for Explaining Amulets Called Serpentines]. Drevnosti: Trudy slavyanskoy komissii imperatorskogo moskovskogo arkheologicheskogo obshchestva, 1895, vol. 1, pp. 134-202.

12. Tolstoy I.I. O russkikh amuletakh, nazyvaemykh zmeevikami [About Russian Amulets Called Serpentines]. Zapiski imperatorskogo russkogo arkheologicheskogo obshchestva, 1888, vol. III, pp. 363-413.

13. Uvarov A.S. Vizantiyskie filakterii i russkie nauzy [Byzantine Phylacteries and Russian Sciences]. Uvarov A.S., ed. Sbornik melkikh trudov [Collection of Minor Works]. Moscow, Tipografiya G. Lissnera i D. Sobko, 1910, vol. 1, pp. 239-258.

14. Barb A.A. Diva Matrix: A Faked Gnostic Intaglio in the Possession of P.P. Rubens and the Iconology of a Symbol. Journal of the Warburg and Courtauld Institutes, 1953, vol. 16, pp. 193-238.

15. Björklund $\mathrm{H}$. Classical Traces of Metamorphosis in the Byzantine Hystera Formula. Dumbarton Oaks Papers, 2016, vol. 70, pp. 151-166.

16. Björklund H. Protecting Against ChildKilling Demons: Uterus Amulets in the Late Antique and Byzantine Magical World: Doctoral Diss. (Article-Based). Helsinki, 2017.82 p.

17. Blankoff J. A propos d'une amulette zmeevik du musée de Vologda. Annuaire de l'Institut de Philologie et d'Histoire orientales et slaves, 1973, vol. XX, pp. 129-135.

18. Blankoff J. O dvoeverii i amuletakh zmeevikakh [About Double Faith and AmuletsSerpentines]. Grashchenkov V.N., ed. Vizantiya, yuzhnye slavyane $i$ drevnyaya Rus, Zapadnaya Evropa [Byzantium, the Southern Slavs and Ancient Rus, Western Europe]. Moscow, Nauka Publ., 1973, pp. 203-210.

19. Blankoff J. Survivances du paganisme en vieille Russie. Problèmes d'histoire du Christianisme, 1979, vol. 8, pp. 29-44.

20. Blankoff J. A propos de la Grivna-Zméevik de Èernigov. Studies on the Slavo-Byzantine and WestEuropean Middle Ages. In memoriam Ivan Dujèev, 1988, vol. I, pp. 123-131.

21. Drexler W. Alte Beschwörungen: 1. Byzantinische Beschwörungen der Ystera und ein italienisches Gebet gegen das male del fianco e di matron. Philologus. Zeitschrift für das klassische Altertum, 1899, vol. 12 (58), no. 1-4, pp. 594-608.

22. Grabar A. Amulettes byzantines du Moyen Age. Puech H.-Ch., ed. Mélanges d' histoire des religions offerts à H.-Ch. Puech. Paris, Presses universitaires de France, 1974, pp. 531-541.

23.Horníeková K. The Power of the Word and the Power of the Image. Towards an Anthropological Interpretation of Byzantine Magical Amulets. Byzantinoslavica, 1998, vol. 59 (2), pp. 239-246.

24. Laurent $\mathrm{V}$. Amulettes byzantines et formulaire magiques. Byzantinische Zeitschrift, 1936, vol. 36, pp. 300-315. 


\section{ВИЗАНТИЙСКОЕ ПРАВОСЛАВИЕ}

25. Schlumberger G. Amulettes byzantins anciens, destinés à combattre les maléfices et maladies. Revue des études grecques, 1892, vol. V, pp. 73-93.

26. Spier J. Medieval Byzantine Magical Amulets and Their Tradition. Journal of the Warburg and Courtauld Institutes, 1993, vol. 56, pp. 25-62.
27. Vikan G. Art, Medecine, and Magic in Early Byzantium. Dumbarton Oaks Papers, 1984, vol.38,pp. 65-86.

28. Zalesskaja V.N. Amulettes byzantines magiques et leur liens avec le littérature apocriphe. Actes du XIV Congrès International des Etudes Byzantines. Bucarest, 1976, vol. III, pp. 243-247.

\section{Information about the Author}

Nikolay D. Barabanov, Candidate of Sciences (History), Associate Professor, Department of Russian and General History, Archaeology, Volgograd State University, Prosp. Universitetsky, 100, 400062 Volgograd, Russian Federation, byzbar@mail.ru, https://orcid.org/0000-0001-7873-5806

\section{Информация об авторе}

Николай Дмитриевич Барабанов, кандидат исторических наук, доцент кафедры отечественной и всеобщей истории, археологии, Волгоградский государственный университет, просп. Университетский, 100, 400062 г. Волгоград, Российская Федерация, byzbar@mail.ru, https://orcid.org/0000-0001-7873-5806 